\title{
Comparison of Three Different Fertigation Strategies for Drip Irrigated Table Grapes - Part I. Soil Water Status, Root System Characteristics and Plant Water Status
}

\author{
P.A. Myburgh* and C.L. Howell \\ ARC Infruitec-Nietvoorbij ${ }^{1}$, Private Bag X5026, 7599, Stellenbosch, South Africa \\ Submitted for publication: May 2012 \\ Accepted for publication: September 2012
}

Key words: Dan-ben-Hannah, open hydroponics, pulse irrigation, soil water status, root density, crop load

\begin{abstract}
Three fertigation strategies were compared in a drip irrigated Dan-ben-Hannah/Ramsey vineyard near Paarl in the Berg River Valley region of South Africa during the 2002/03 and 2003/04 seasons. Fertilisers were applied either (i) three times per season, (ii) once a week from bud break to flowering, from fruit set to véraison and for six weeks after harvest or (iii) in five to seven pulses per day. For each of the fertigation strategies, grapevines bore normal or high crop loads, viz. 26 or 36 bunches per grapevine respectively. Daily irrigation pulses of 20 to 40 minutes each maintained soil water matric potential above -0.01 MPa in the wetted bulbs. Daily pulses accumulated to a seasonal total of $c a .490 \mathrm{~mm}$ irrigation compared to $c a .260$ $\mathbf{m m}$ for weekly irrigation. Root structures of grapevines irrigated by means of daily pulses had adapted by forming extremely dense root systems in the small wetted bulbs compared to the less frequently irrigated grapevines. Monitoring diurnal grapevine water status revealed that the different fertigation strategies did not affect water constraints up to véraison. During berry ripening, daily pulse irrigated grapevines experienced less water constraints in the morning, late afternoon and during the night than less frequently irrigated ones. However, the grapevines did not experience any detrimental water constraints throughout the season, irrespective of fertigation and irrigation frequencies or crop load. It was evident that grapevine water status not only depends on the size of the root structure, but also on the soil environment in which the roots function.
\end{abstract}

\section{INTRODUCTION}

Many factors, notably climate, soil, water and vineyard management, can influence the growth and yield of export table grapes (Pérez-Harvey, 2008). For profitable export of table grapes, berries and bunches must not only conform to size, colour and shape standards, but also have a balanced sugar to acid content. Since growth, yield and fruit quality of table grapes depend on grapevine water status (Van Rooyen et al., 1980; Fourie, 1989; Myburgh, 1996; El-Ansary et al., 2005; Myburgh \& Howell, 2006, 2007), irrigation is an important management practice to help ensure the economically viable production of export grapes. Water is becoming an increasingly scarce resource. Therefore, irrigation strategies are continuously being developed or refined to optimise grape quality without reducing yield. In this regard, water can be applied more efficiently by means of drip irrigation systems compared to ones that wet the total surface (Ley, 1994). Furthermore, if climate change results in drier winters in the Western Cape Province, it could reduce the amount of water available for the replenishment of underground water resources and dams that store winter water for irrigation during summer.

Plant nutrients are being applied in many table and wine grape vineyards by means of drip fertigation systems (Bravdo, 2000). Fertigation can be defined as the application of fertilisers through irrigation systems (Komosa et al., 1999b; Conradie \& Myburgh, 2000; Treder, 2005; Sharma et al., 2008). Although the impact of fertigation on fruit trees has been studied intensively (Komosa et al., 1999a), research on the fertigation of grapevines is limited (Reynolds et al., 2005). Since drip fertigation results in partial wetting of the total soil volume, it creates gradients of soil water content and mineral concentrations across the root systems (Bravdo, 2008). However, the application of nutrients to a small wetted volume where active roots are concentrated is considered more precise and uniform than irrigation systems that wet the total soil volume (Sharma et al., 2008). Fertigation could reduce ground water pollution (Komosa et

\footnotetext{
${ }^{1}$ The Fruit, Vine and Wine Institute of the Agricultural Research Council

*Corresponding author: myburghp@arc.agric.za

Acknowledgements: The ARC for infrastructure and other resources, Deciduous Fruit Producers' Trust for partial funding, the Soil and Water Science staff at ARC Infruitec-Nietvoorbij for technical support and Mr. A. Hoekstra for permission to work in his vineyard
} 
al., 1999a) and labour costs (Sharma et al., 2008). It also enables the regulation of nutrient amounts and application frequency according to the plants' requirements (Treder, 2005). Therefore, fertigation has the potential to ensure the accurate application of daily water and nutrient requirements through the irrigation system. Due to some similarities to the hydroponic systems used in glass houses, daily fertigation is generally referred to by the table grape industry as "open hydroponics" when applied under field conditions. The word "hydroponics" originates from the Greek "hydro", meaning water, and "ponic", meaning work (Mollafilabi et al., 2010). This implies that hydroponically grown plants are actually independent of soil, which is certainly not the case in vineyards. There are many advantages to hydroponics, such as higher yields, improved water and fertiliser economy, as well as lower environmental pollution (Mollafilabi et al., 2010). Cut flowers (Fascella \& Zizzo, 2005), tomatoes (Maboko \& Du Plooy, 2008; Maboko et al., 2009) and other vegetables (Dasgan \& Ekici, 2005) are produced using hydroponics, which enables better control of plant growth and development. However, the implementation of this concept can be expensive and difficult to manage (Fascella \& Zizzo, 2005).

Due to partial soil wetting, drip irrigation can induce more water constraints in grapevines than full-surface irrigation. A previous study showed that drip irrigated Barlinka table grapes in a coarse, sandy soil in the Hex River Valley consistently experienced more water constraints from flowering until harvest than micro-sprinkler irrigated grapevines (Myburgh, 1996). In this study, grapevines were irrigated by both systems when $40 \%$ of the plant available water (PAW) was depleted. In the case of drip irrigation, frequent low-volume applications of water and minerals are required (Bravdo, 2000 ) in order to maintain root development, soil water availability and aeration, and to prevent water and minerals from percolating to deeper layers (Bravdo, 2008). However, grapevines in more fertile soils could produce equally high yields under almost any irrigation system if irrigation scheduling is managed properly (Van Zyl, 1984; Myburgh, 2007). Since the success of a fertigation strategy that entails daily irrigation pulses depends on optimal water supply to the plants, thereby enabling unconstrained physiological functioning, this strategy should only allow minimal water constraints to develop in the grapevines, particularly if drip irrigation is used.

The objective of this study was to determine if water constraints in drip-fertigated grapevines could be minimised and maintained, particularly where daily irrigation pulses are applied.

\section{MATERIALS AND METHODS \\ Experiment vineyard}

The field trial was carried out in a twenty-three-year-old drip irrigated Dan-ben-Hannah/Ramsey vineyard near Paarl in the Berg River Valley region of the Western Cape Province. Dan-ben-Hannah, also known as Black Emperor, originated in Israel, where it was selected from a cross between Black Mikveh and Alphonse Lavallee (Hurndall, 2005). Air temperature, vapour pressure deficit (VPD), reference evapotranspiration $\left(\mathrm{ET}_{\mathrm{O}}\right)$ and rainfall data were obtained from the ARC Institute for Soil, Climate and Water in Pretoria (Table 1). The region has a Mediterranean climate with warm, dry summers. Based on the growing degree days (GDD) from September until March (Winkler, 1962), the specific locality is in a class $\mathrm{V}$ climatic region for viticulture (Le Roux, 1974). The soil, which belongs to the Avalon form (Soil Classification Work Group, 1991), consists of a 300 mm deep sandy orthic A horizon on a $400 \mathrm{~mm}$ deep sandy clay loam yellow-brown apedal B1 horizon overlaying a soft plinthic B2 horizon. The soil was ploughed to a depth of $900 \mathrm{~mm}$ using a crawler tractor before the vineyard was established. Grapevines were spaced $3.0 \mathrm{~m}$ x $1.8 \mathrm{~m}$ and trained onto a Gable trellis (Avenant, 1991).

\section{Experiment layout}

The factorial experiment layout consisted of three fertilisation strategies replicated six times. The low frequency fertigated (LF) grapevines received fertilisers at bud break, fruit set and post-harvest. The weekly fertigated (WF) grapevines received the same amount of fertiliser as the LF ones, but in weekly applications from bud break to flowering, from fruit set to véraison and for six weeks after harvest. The third strategy entailed daily fertigation (DF) according to the nutrient requirements of the grapevines. Fertilisers were injected into the irrigation water by means of a commercial system (Eldar Shany, Israel). Further details on the fertilisation of the grapevines will be presented in a subsequent article. Each experiment plot comprised a row of sixteen grapevines, with two border grapevines at each end and a border row on each side to minimise overlapping treatment effects. In each main plot, bunches on eight of the grapevines used in the experiment were thinned out to obtain a normal crop load $(\mathrm{N})$, which is 26 bunches per grapevine for Dan-ben-Hannah under the given conditions. The remaining grapevines were manipulated to bear a relatively high crop load $(\mathrm{H})$ of 36 bunches per grapevine. In each sub-plot, bunches were counted to obtain the exact crop load level. Bunch removal was carried out in November. The three fertigation strategies were only applied fully from the beginning of December 2001. Since the different crop load level treatments were also not applied, the 2001/02 season was merely considered a pilot year. During the 2002/03 and 2003/04 seasons, the six treatments were applied from bud break in September until the end of March, when the first autumn rains occurred. Hence, only results obtained in the latter seasons will be reported and discussed.

\section{Irrigation and soil water status}

In the case of the LF and WF strategies, 3.5 L/h drippers were spaced $600 \mathrm{~mm}$ apart in the irrigation lines, i.e. two drippers per grapevine and a shared one halfway between two grapevines. Where daily pulses were applied, grapevines were irrigated by means of $1.8 \mathrm{~L} / \mathrm{h}$ drippers, also spaced $600 \mathrm{~mm}$ apart. Mercury manometer tensiometers were used to monitor the soil water matric potential $\left(\Psi_{\mathrm{m}}\right)$ of the LF and WF strategies. Initially, $\Psi_{\mathrm{m}}$ was measured only at depths of $300 \mathrm{~mm}$ and $600 \mathrm{~mm}$, but from November $2002 \Psi_{\mathrm{m}}$ was also measured at $900 \mathrm{~mm}$. In the case of the DF strategy, the objective was to maintain $\Psi_{\mathrm{m}}$ in the wetted "bulbs" above ca. $-0.01 \mathrm{MPa}$ during the day. To ensure that the correct 
irrigation volumes were applied to maintain these relatively high potentials, $\Psi_{\mathrm{m}}$ was monitored at 15 -minute intervals using automatically recording tensiometers fitted with vacuum transducers (Soil, Water \& Waste Instrumentation, Pietermaritzburg). Each vacuum transducer was calibrated to convert its output $(\mathrm{mV})$ to $\Psi_{\mathrm{m}}$. The automatically recording tensiometers were installed next to a dripper at $75 \mathrm{~mm}, 150$ $\mathrm{mm}$ and $300 \mathrm{~mm}$ depths. Water distribution in the soil around the wetted bulbs of the DF strategy was monitored manually by means of mercury manometer tensiometers installed 200 $\mathrm{mm}$ from a dripper at $150 \mathrm{~mm}, 300 \mathrm{~mm}$ and $600 \mathrm{~mm}$ depths. Tensiometers were also installed $100 \mathrm{~mm}$ from drippers at a depth of $75 \mathrm{~mm}$. Irrigation lines lay on the soil surface and were anchored to the upright posts of the trellis system to prevent the drippers from shifting around. Irrigation volumes were monitored using flow meters. Soil water status and irrigation volumes were measured in three replications of the different fertigation strategies. Determining soil water balances and calculating crop coefficients to estimate vineyard evapotranspiration from $\mathrm{ET}_{\mathrm{O}}$ were beyond the scope of the study.

\section{Root studies}

The basic structures of the root systems were determined in five replications of each fertigation strategy during October 2004, after completion of the field trial. The profile wall method of Böhm (1979) was used to qualify root distribution within the constraints of the technique. A trench, $c a .3 \mathrm{~m}$ long and $1 \mathrm{~m}$ deep, was excavated across the grapevine row between two of the grapevines in the experiment row, with the long sides of the trench $c a .100 \mathrm{~mm}$ from the grapevines. After the roots were carefully exposed, a $100 \mathrm{~mm} \times 100$ $\mathrm{mm}$ portable wire grid was placed against the profile wall for mapping of the roots. Roots were classified according to their diameter $(\mathrm{d})$ into four classes, namely fine $(\mathrm{d} \leq 0.5$ $\mathrm{mm})$, medium $(0.5 \mathrm{~mm}<\mathrm{d} \leq 2.0 \mathrm{~mm})$, coarse $(2.0 \mathrm{~mm}<\mathrm{d} \leq$ $5.0 \mathrm{~mm})$ and thick $(\mathrm{d}>5.0 \mathrm{~mm})$.

\section{Grapevine water status}

Diurnal changes in grapevine water status were quantified by measuring leaf water potential $\left(\Psi_{\mathrm{L}}\right)$ by means of the pressure chamber technique (Scholander et al., 1965), according to the protocol described by Myburgh (2010). On 7 January 2003 (during berry ripening), $\Psi_{\mathrm{L}}$ was measured every two hours from 04:00 until 02:00 the following morning. In the 2003/04 season, these measurements were repeated on 28 October 2003 (around flowering), 15 December 2003 (prior to véraison) and 19 January 2004 (during berry ripening). Since no bunches had been removed in October, the effect of crop load on grapevine water status could not be determined at that stage. Leaf water potential was measured in one mature, unscathed leaf on a primary shoot per plot in four replications of the six treatments. During daytime, $\Psi_{\mathrm{L}}$ was measured in leaves fully exposed to the sun. Total diurnal leaf water potential $\left(\Psi_{\text {Tot }}\right)$ was calculated from the twohourly data using the trapezoidal rule (Larson et al., 1994), as described by Myburgh and Howell (2006).

\section{Statistical analysis}

The data were subjected to an analysis of variance using

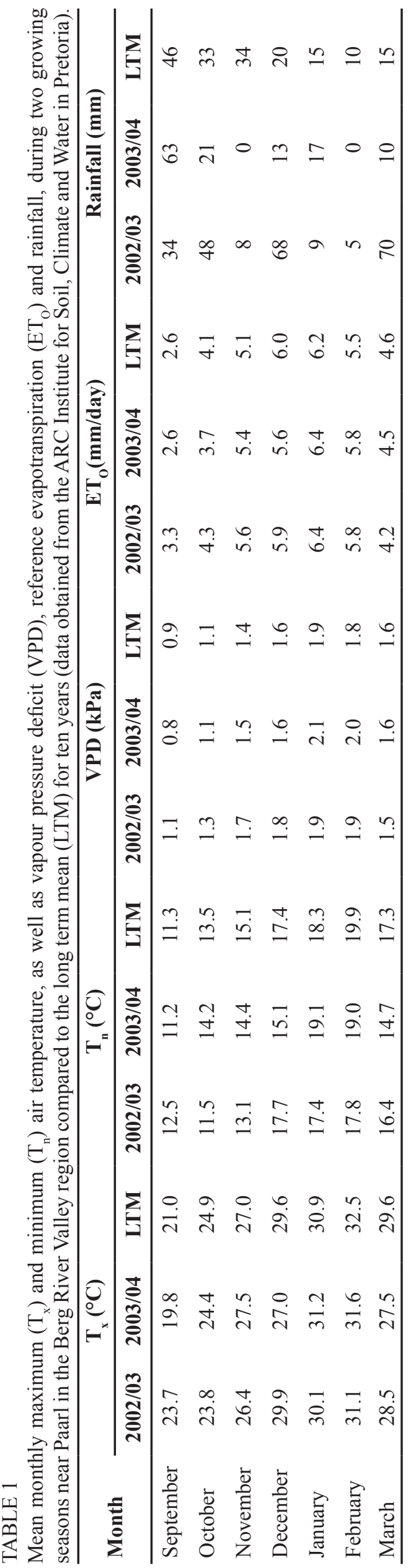


Statgraphics ${ }^{\circledR}$. Least significant difference (LSD) values were calculated to facilitate comparison between treatment means. Means that differed at $p \leq 0.05$ were considered to be significantly different.

\section{RESULTS AND DISCUSSION}

\section{Soil water status}

\section{Low frequency and weekly fertigation strategies}

The atmospheric conditions were comparable to the long term means during both seasons (Table 1). Hence, adverse weather could not have caused abnormal grapevine water use or constraints in any of the seasons. A total of approximately $80 \mathrm{~mm}$ rainfall in September and October occurred in both seasons. Due to this rainfall, the soil remained wet until October in both seasons. However, grapevines of the LF and WF strategies received four to five irrigations of $c a .2 \mathrm{~mm}$ each to allow fertiliser application during October and in the first half of November. Since the soil was wet, these small irrigations did not affect the soil water status markedly. In both seasons, the first "full" irrigations were applied during November. In the 2002/03 season, two to three irrigations were applied per week during November and December
(Table 2). At these intervals, $\Psi_{\mathrm{m}}$ remained relatively high to a depth of $300 \mathrm{~mm}$, but the irrigation volumes were too small to wet the subsoil to a depth of $900 \mathrm{~mm}$ (Fig. 1). When three irrigations per week were maintained in January and February, $\Psi_{m}$ remained higher than $-0.03 \mathrm{MPa}$ to a depth of $600 \mathrm{~mm}$, but continued to dry out gradually at $900 \mathrm{~mm}$. In the 2003/04 season, the LF and WF grapevines received only two irrigations during November (Fig. 2). From December onwards, the LF and WF grapevines received weekly irrigation until the post-harvest period in March. By applying higher irrigation volumes at weekly intervals (Table 2), $\Psi_{\mathrm{m}}$ in the topsoil varied between -0.01 MPa and $-0.03 \mathrm{MPa}$ before irrigations were applied, whereas $\Psi_{\mathrm{m}}$ varied between $-0.03 \mathrm{MPa}$ and $-0.05 \mathrm{MPa}$ at a depth of 600 $\mathrm{mm}$. The gravelly nature of the subsoil probably reduced the water holding capacity, which caused low $\Psi_{\mathrm{m}}$ to develop between irrigations compared to the topsoil. At $900 \mathrm{~mm}$ depth, $\Psi_{m}$ decreased to $c a$. $-0.055 \mathrm{MPa}$ before the irrigations were applied (Fig. 2). In both seasons, the seasonal irrigation volumes were approximately $36 \%$ lower compared to a ten-year average of $411 \mathrm{~mm}$ where Barlinka table grapes were drip fertigated every second day in the Hex River

\section{TABLE 2}

Monthly irrigations and amounts of irrigation water applied to the low frequency and weekly fertigated grapevines during two growing seasons near Paarl in the Berg River Valley region.

\begin{tabular}{|c|c|c|c|c|c|c|}
\hline \multirow[t]{2}{*}{ Month } & \multicolumn{3}{|c|}{ 2002/03 Season } & \multicolumn{3}{|c|}{ 2003/04 Season } \\
\hline & $\begin{array}{l}\text { Number of } \\
\text { irrigations }\end{array}$ & $\begin{array}{l}\text { Irrigation } \\
\quad(\mathrm{mm})\end{array}$ & $\begin{array}{l}\text { Total } \\
(\mathrm{mm})\end{array}$ & $\begin{array}{l}\text { Number of } \\
\text { irrigations }\end{array}$ & $\begin{array}{l}\text { Irrigation } \\
(\mathbf{m m})\end{array}$ & $\begin{array}{l}\text { Total } \\
(\mathrm{mm})\end{array}$ \\
\hline November & 6 & 5.2 & 31.2 & 2 & 14.8 & 29.6 \\
\hline December & 9 & 5.5 & 49.3 & 4 & 12.4 & 49.7 \\
\hline January & 12 & 5.5 & 66.0 & 4 & 16.5 & 65.8 \\
\hline February & 12 & 5.6 & 66.8 & 4 & 16.5 & 66.1 \\
\hline $\operatorname{March}^{(1)}$ & 7 & 6.2 & 43.5 & 4 & 13.0 & 52.0 \\
\hline Total $(\mathrm{mm})$ & & & 257 & & & 266 \\
\hline
\end{tabular}

(1) Treatment application stopped at the end of March.

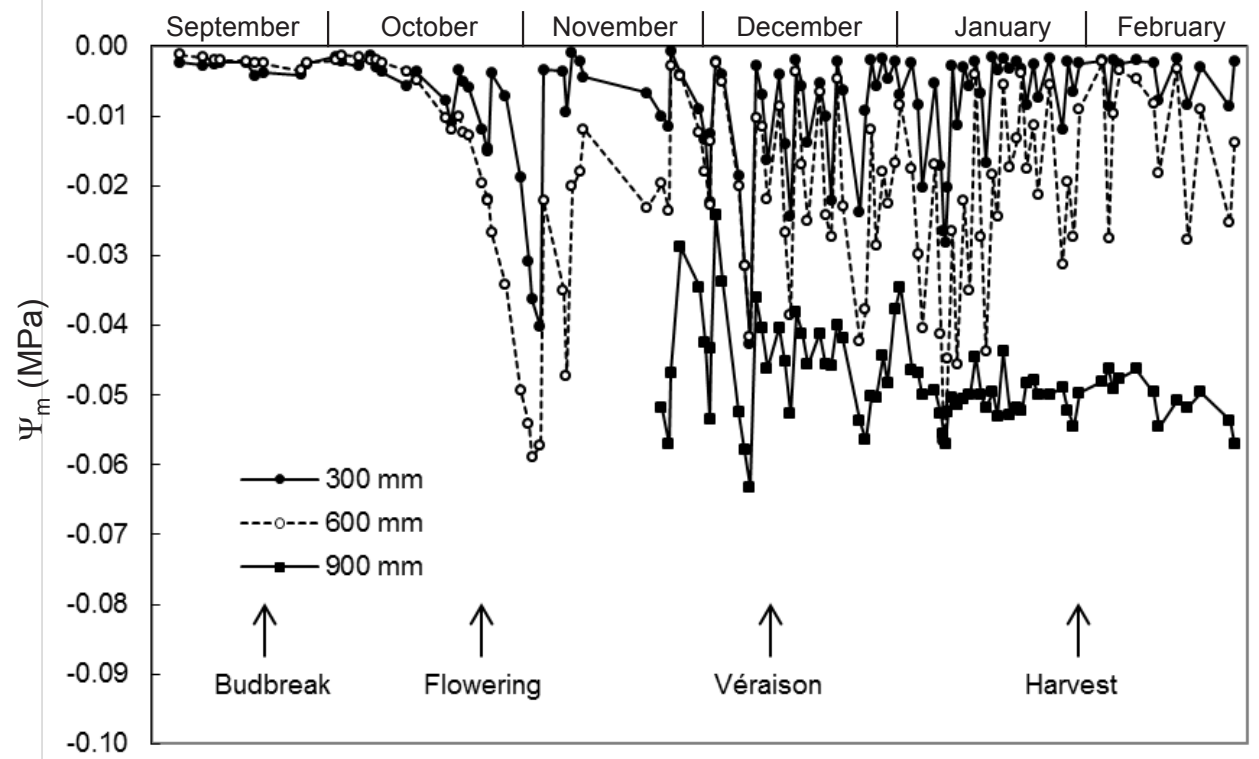

FIGURE 1

Seasonal variation in soil water matric potential $(\Psi \mathrm{m})$ where low frequency and weekly fertigation were applied during the 2002/03 season near Paarl in the Berg River Valley region. 
Valley (Saayman \& Lambrechts, 1995). Due to the limited soil wetting, the drip irrigation volumes were respectively $54 \%, 61 \%$ and $70 \%$ lower than the $569 \mathrm{~mm}$ (Saayman \& Lambrechts, 1995), $663 \mathrm{~mm}$ (Fourie, 1989) and $879 \mathrm{~mm}$ (Myburgh \& Howell, 2007) that have been reported for micro-sprinkler irrigated table grapes.

\section{Daily irrigation pulses}

In the case of the DF strategy, the soil remained wet at 75 $\mathrm{mm}$ at a distance of $100 \mathrm{~mm}$ from the drippers throughout the season, whereas $200 \mathrm{~mm}$ away from the drippers, the soil dried out as the season progressed (Fig. 3). Right next to the drippers, $\Psi_{\mathrm{m}}$ was never below $-0.005 \mathrm{MPa}$ at depths of $75 \mathrm{~mm}$ and $150 \mathrm{~mm}$ (data not shown). On the basis of these results, the wetted bulbs did not seem to exceed $200 \mathrm{~mm}$ in diameter and $300 \mathrm{~mm}$ in depth. However, where daily irrigation pulses were applied, the soil outside the wetted bulbs occasionally became wetter. The wetted soil volume expanded when the weather was cool and overcast, which suggests that the irrigation volumes exceeded the evapotranspiration losses, thereby allowing water to spread laterally and percolate to the deeper soil layers. It should be noted that no rainfall occurred during any of these overcast periods when increases in the wetted volumes were observed. During the 2002/03 growing season, $\Psi_{\mathrm{m}}$ in the wetted bulbs of the DF strategy decreased below $-0.01 \mathrm{MPa}$ early in January, particularly during the afternoon and night. The excessive drying was caused by extremely warm conditions, viz. maximum air temperatures in excess of $35^{\circ} \mathrm{C}$ (data not shown). However, $\Psi_{\mathrm{m}}$ remained above $-0.01 \mathrm{MPa}$ when two additional irrigation pulses of 20

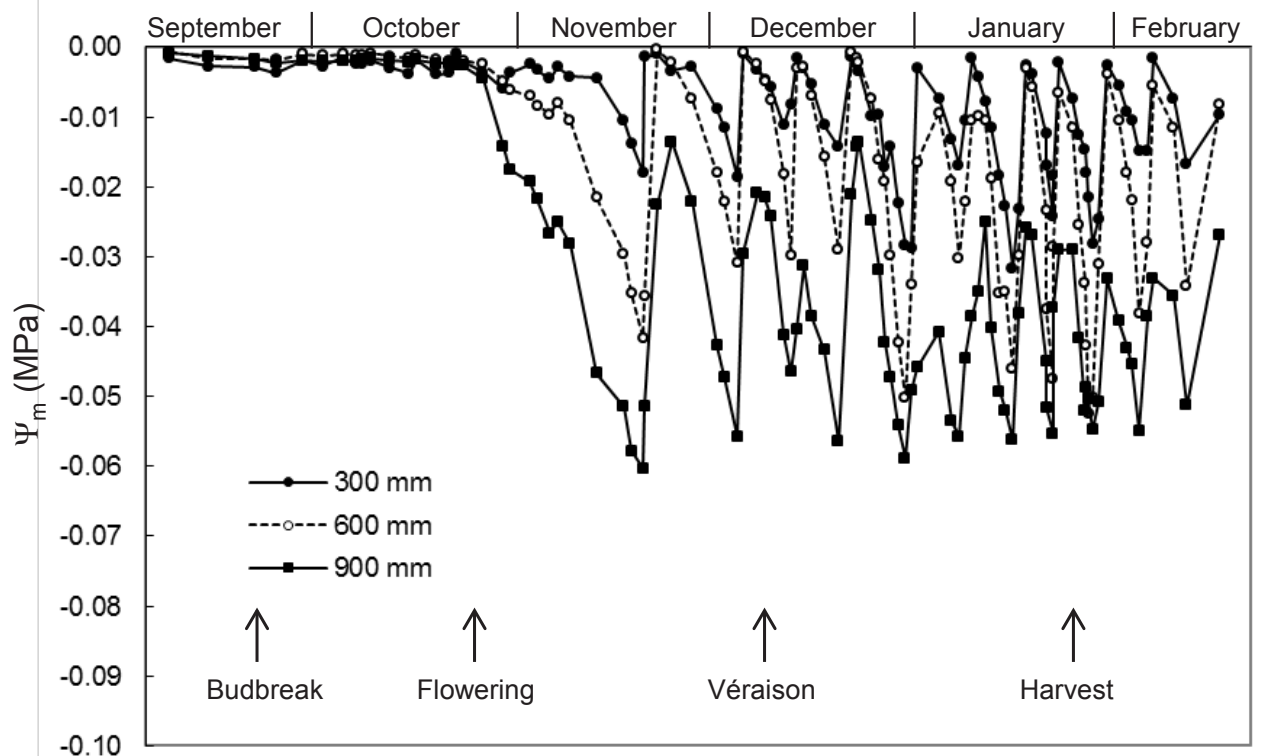

FIGURE 2

Seasonal variation in soil water matric potential $\left(\Psi_{\mathrm{m}}\right)$ where low frequency and weekly fertigation were applied during the 2003/04 season near Paarl in the Berg River Valley region.

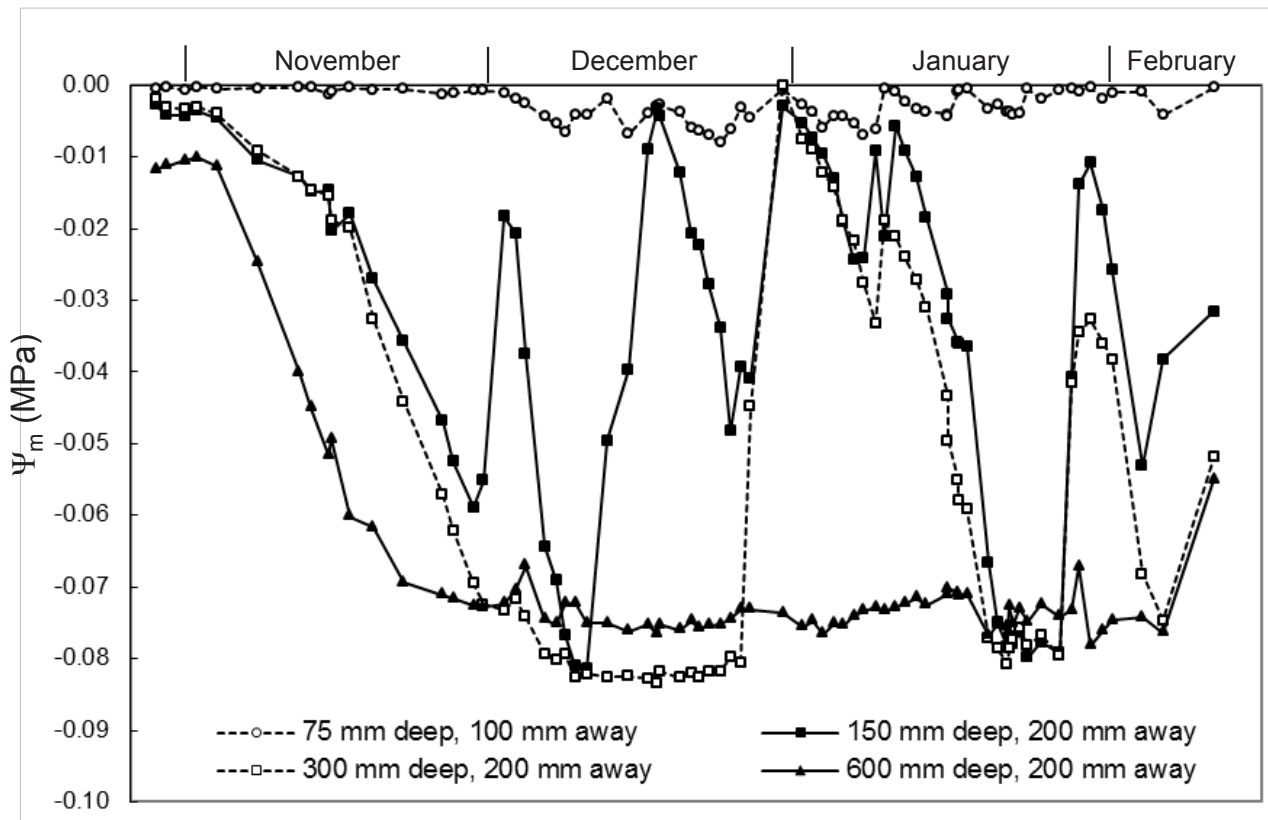

FIGURE 3

Variation in soil water matric potential $\left(\Psi_{\mathrm{m}}\right)$, as measured at different depths and distances from drippers, where pulse irrigation was applied daily during the 2003/04 season near Paarl in the Berg River Valley region. 
TABLE 3

Number and duration of irrigation pulses, as well as the amount of water applied, where grapevines received daily irrigation pulses during the 2002/03 season near Paarl in the Berg River Valley region.

\begin{tabular}{|c|c|c|c|c|c|c|}
\hline Month & $\begin{array}{l}\text { Number } \\
\text { of pulses } \\
\text { per day }\end{array}$ & $\begin{array}{c}\text { Pulse } \\
\text { duration } \\
\text { (minutes) }\end{array}$ & $\begin{array}{c}\text { Irrigation per } \\
\text { grapevine per pulse } \\
\text { (L) }\end{array}$ & $\begin{array}{c}\text { Irrigation per } \\
\text { grapevine per day } \\
\text { (L) }\end{array}$ & $\begin{array}{c}\text { Irrigation } \\
\text { per day } \\
(\mathrm{mm}) \\
\end{array}$ & $\begin{array}{c}\text { Irrigation } \\
\text { per month } \\
(\mathrm{mm}) \\
\end{array}$ \\
\hline September & 1 & 30 & 2.70 & 2.7 & 0.5 & 15.0 \\
\hline October & 1 & 30 & 2.70 & 2.7 & 0.5 & 15.5 \\
\hline November & 2 & 30 & 2.70 & 5.4 & 1.0 & 30.0 \\
\hline December & 5 & 25 & 2.25 & 11.3 & 2.1 & 64.6 \\
\hline January & 5 & 40 & 3.60 & 21.6 & 4.0 & 124.0 \\
\hline & 2 & 20 & 1.80 & - & - & - \\
\hline February & 5 & 40 & 3.60 & 21.6 & 4.0 & 112.0 \\
\hline & 2 & 20 & 1.80 & - & - & - \\
\hline March & 3 & 35 & 3.15 & 9.5 & 1.8 & 54.3 \\
\hline April & 3 & 35 & 3.15 & 9.5 & 1.8 & 52.5 \\
\hline May to August & (1) & 30 & 2.70 & 2.7 & 0.5 & 6.0 \\
\hline
\end{tabular}

(1) Only three pulses per week to enable fertiliser application.

minutes each were applied over the warmest part of the day (Table 3). The rainfall recorded in January only occurred in the week before harvest. Due to low rainfall, and the risk of more heat waves, the two additional pulses were maintained until the end of February.

In the 2003/04 growing season, the two DF treatments were irrigated as in 2002/03, except that only five daily pulses were applied during January and February. Although atmospheric conditions tended to be slightly warmer and drier in the 2003/04 season than in 2002/03 (Table 1), it was not necessary to apply additional pulses in January and February (data not shown). Three almost evenly spaced rainfall events of $\mathrm{ca} .5 \mathrm{~mm}$ each in the three weeks before the grapes were harvested on 26 January 2004 seemed to have reduced the need for additional pulses. Due to the additional pulses, irrigation amounted to $492 \mathrm{~mm}$ in the 2002/03 season, whereas only $423 \mathrm{~mm}$ was applied in 2003/04. This means that the DF irrigated grapevines received ca. $91 \%$ and $59 \%$ more irrigation than the LF and WF grapevines in the 2002/03 and 2003/04 seasons respectively. Applications of the DF strategy were also substantially higher in the 2002/03 season than the $411 \mathrm{~mm}$ reported for drip fertigated Barlinka in a sandy soil (Saayman \& Lambrechts, 1995).

\section{Root system characteristics}

The root systems of the grapevines consisted primarily of fine roots, irrespective of fertigation strategy (data not shown). This trend agreed with previous results reported for drip irrigated grapevines (Myburgh, 1996, 2007, 2011b). In the case of the LF and WF strategies, roots occurred throughout the profile, but beneath the dripper lines mean root density was 580 roots $/ \mathrm{m}^{2}$ to a depth of $1 \mathrm{~m}$ (Fig. $4 \mathrm{~A}$ ). This was comparable to root densities beneath the dripper lines of $c a$. 600 roots $/ \mathrm{m}^{2}$ reported for Barlinka/Ramsey in a sandy soil (Myburgh, 1996). Similarly, root density was $c a$. 400 to $600 \mathrm{roots} / \mathrm{m}^{2}$ where Sultanina/143B Mgt was grown for raisin production in a sandy loam alluvial soil (Myburgh, 2007). Where grapevines were fertigated according to the DF strategy, mean root density beneath the dripper lines was ca. 710 roots $/ \mathrm{m}^{2}$ to a depth of $1 \mathrm{~m}$ (Fig. 4B). The higher mean root density was primarily due to a density of $c a$. $1100 \mathrm{roots} / \mathrm{m}^{2}$ within the wetted bulbs of the daily pulse irrigation strategy. Furthermore, it appeared as if roots in the work rows and deeper layers of the DF strategy had died, compared to the low frequency and weekly fertigated grapevines. The extremely high root density confirmed that the wetted bulbs did not exceed $c a .200 \mathrm{~mm}$ in width and $c a$. $300 \mathrm{~mm}$ in depth, as discussed above. It has been reported previously that the occupation of a limited soil volume by roots in the case of drip irrigated plants is quite efficient, and that a dense root population develops rapidly (Bravdo, 2000). Furthermore, the formation of fine feeder roots is a typical physiological response to root restriction and is apparent when plants grow in small containers. These results showed that the roots of well-functioning grapevines do not necessarily need exposure to uniform soil water conditions. It was previously concluded that grapevine roots near the soil surface often encounter extremely different soil moisture conditions compared to roots in deeper soil layers (Comas et al., 2010).

\section{Grapevine water status \\ Predawn water status}

Grapevine water status measured in the 2002/03 and 2003/04 seasons is presented in Tables 4 and 5. The high predawn $\left(\Psi_{\mathrm{PD}}\right)$ values around flowering and véraison indicate that the grapevine water status could recover during the night, irrespective of fertigation strategy (Table 5). Since $\Psi_{\mathrm{PD}}$ was higher than $-0.2 \mathrm{MPa}$, grapevines experienced no water constraints according to the classification based on $\Psi_{\mathrm{PD}}$ proposed by Deloire et al. (2004). At véraison, crop load had no effect on the ability of grapevine water status 
to recover during the night. However, this might not be the case if drier soil conditions induce high or severe water constraints in the grapevines. During berry ripening (Tables 4 \& 5), the high $\Psi_{\mathrm{PD}}$ was comparable to values found in Sultanina irrigated at $30 \%$ PAW depletion, i.e. $\Psi_{\mathrm{m}}$ more than -0.015 MPa (Myburgh, 2003), and Sunred Seedless irrigated at $20 \%$ PAW depletion, i.e. $\Psi_{m}$ more than -0.003 MPa (Myburgh \& Howell, 2006). Since the latter cultivars were irrigated by means of micro-sprinklers, the high $\Psi_{\mathrm{PD}}$ in the drip fertigated grapevines indicate that drip irrigation
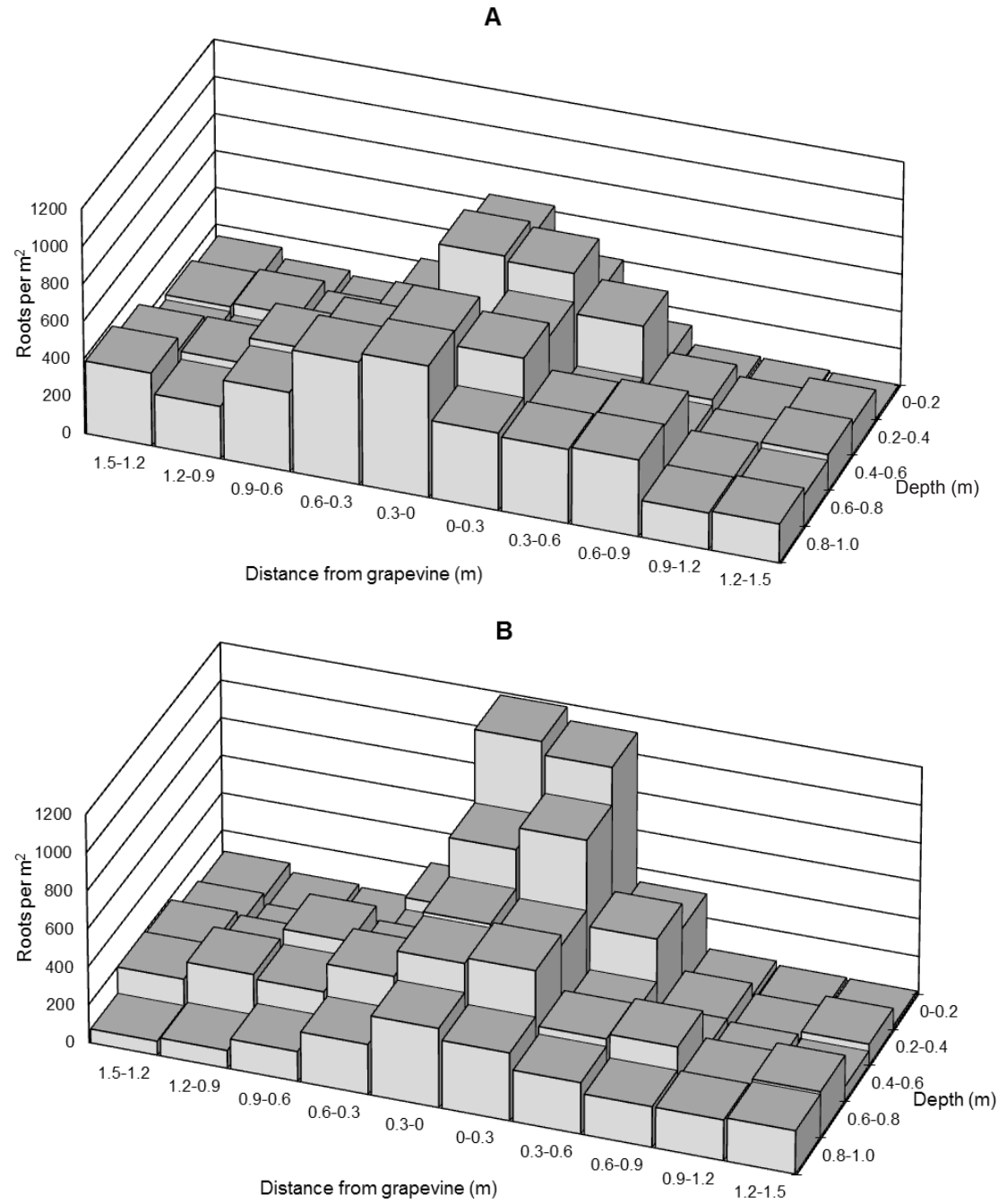

FIGURE 4

Root distribution and density beneath dripper lines where (A) fertilisers were applied at a low frequency or weekly and (B) pulse irrigation was applied daily.

TABLE 4

Effect of low frequency (LF), weekly (WF) and daily pulse (DF) fertigation and crop load on predawn $\left(\Psi_{\mathrm{PD}}\right)$, midday leaf $\left(\Psi_{\mathrm{L}}\right)$ and total diurnal $\left(\Psi_{\text {Tot }}\right)$ water potential in Dan-ben-Hannah grapevines determined during berry ripening in the 2002/03 season near Paarl in the Berg River Valley region.

\begin{tabular}{|c|c|c|c|c|c|}
\hline \multirow{2}{*}{ Treatment } & \multirow{2}{*}{$\begin{array}{l}\text { Fertigation } \\
\text { strategy }\end{array}$} & \multirow{2}{*}{$\begin{array}{l}\text { Irrigation } \\
\text { frequency }\end{array}$} & \multicolumn{3}{|c|}{ Grapevine water potential } \\
\hline & & & $\Psi_{\text {PD }}$ (MPa) & $\Psi_{\mathrm{L}}$ (MPa) & $\Psi_{\text {Tot }}\left(\mathrm{MPa}^{2}\right)$ \\
\hline $\mathrm{LF}_{\mathrm{N}}^{(1)}$ & 3 times/season & 3 irrigations per week & $-0.13 \mathrm{a}^{(2)}$ & $-1.10 \mathrm{a}$ & $14.5 \mathrm{~b}$ \\
\hline $\mathrm{LF}_{\mathrm{H}}$ & 3 times/season & 3 irrigations per week & $-0.13 \mathrm{a}$ & $-1.19 \mathrm{a}$ & $15.2 \mathrm{ab}$ \\
\hline $\mathrm{WF}_{\mathrm{N}}$ & weekly & 3 irrigations per week & $-0.11 \mathrm{a}$ & $-1.13 \mathrm{a}$ & $15.1 \mathrm{ab}$ \\
\hline $\mathrm{WF}_{\mathrm{H}}$ & weekly & 3 irrigations per week & $-0.13 \mathrm{a}$ & $-1.18 \mathrm{a}$ & $15.9 \mathrm{a}$ \\
\hline $\mathrm{DF}_{\mathrm{N}}$ & daily pulses & daily pulses & $-0.09 \mathrm{a}$ & $-1.15 \mathrm{a}$ & $12.0 \mathrm{c}$ \\
\hline $\mathrm{DF}_{\mathrm{H}}$ & daily pulses & daily pulses & $-0.09 a$ & $-1.12 \mathrm{a}$ & $12.0 \mathrm{c}$ \\
\hline
\end{tabular}

(1) $\mathrm{N}=$ normal crop load, i.e. 26 bunches per grapevine, and $\mathrm{H}=$ high crop load, i.e. 36 bunches per grapevine.

(2) Values designated by the same letter within each column do not differ significantly $(\mathrm{p} \leq 0.05)$. 
TABLE 5

Effect of low frequency (LF), weekly (WF) and daily pulse (DF) fertigation and crop load on predawn leaf water potential ( $\left.\Psi_{\mathrm{PD}}\right)$ during various growth stages in Dan-ben-Hannah grapevines determined during the 2003/04 season near Paarl in the Berg River Valley region.

\begin{tabular}{|c|c|c|c|c|c|}
\hline \multirow{2}{*}{ Treatment } & \multirow{2}{*}{$\begin{array}{l}\text { Fertigation } \\
\text { strategy }\end{array}$} & \multirow{2}{*}{$\begin{array}{l}\text { Irrigation } \\
\text { frequency }\end{array}$} & \multicolumn{3}{|c|}{$\Psi_{\mathrm{PD}}(\mathrm{MPa})$} \\
\hline & & & Flowering $^{(1)}$ & Véraison & Berry ripening \\
\hline $\mathrm{LF}_{\mathrm{N}}^{(2)}$ & 3 times/season & weekly & $-0.06 \mathrm{a}^{(3)}$ & $-0.05 \mathrm{a}$ & $-0.17 b$ \\
\hline $\mathrm{LF}_{\mathrm{H}}$ & 3 times/season & weekly & - & $-0.05 \mathrm{a}$ & $-0.14 b$ \\
\hline $\mathrm{WF}_{\mathrm{N}}$ & weekly & weekly & $-0.09 \mathrm{a}$ & $-0.03 \mathrm{a}$ & $-0.14 b$ \\
\hline $\mathrm{WF}_{\mathrm{H}}$ & weekly & weekly & - & $-0.04 \mathrm{a}$ & $-0.13 b$ \\
\hline $\mathrm{DF}_{\mathrm{N}}$ & daily pulses & daily pulses & $-0.06 \mathrm{a}$ & $-0.05 \mathrm{a}$ & $-0.05 \mathrm{a}$ \\
\hline $\mathrm{DF}_{\mathrm{H}}$ & daily pulses & daily pulses & - & $-0.05 \mathrm{a}$ & $-0.04 \mathrm{a}$ \\
\hline
\end{tabular}

(1) No bunches were removed at that stage.

${ }^{(2)} \mathrm{N}=$ normal crop load, i.e. 26 bunches per grapevine, and $\mathrm{H}=$ high crop load, i.e. 36 bunches per grapevine.

(3) Values designated by the same letter within each column do not differ significantly $(\mathrm{p} \leq 0.05)$.

does not necessarily have negative effects on water status recovery in grapevines during the night. When measured in the 2002/03 season, the DF strategy only tended to lower the predawn water constraints compared to three irrigations per week. However, when measured in the 2003/04 season, daily pulse irrigation caused an almost threefold increase in $\Psi_{\mathrm{PD}}$ compared to weekly irrigation (Table 5). This result indicates that the DF strategy had a positive effect on predawn grapevine water status, although the different fertigation strategies did not induce any water constraints according to the $\Psi_{\text {PD }}$ classification. This suggests that the water constraint classification based on $\Psi_{\mathrm{PD}}$ should be adapted to include a class to distinguish between levels of grapevine water status when soil water availability is in the high range. Such an "ultra-low" constraint class, viz. $-0.1 \mathrm{MPa}>\Psi_{\mathrm{PD}} \geq-0.2 \mathrm{MPa}$, could be a meaningful measure of water status, particularly for the management of table grape irrigation.

\section{Midday water status}

The grapevines experienced no midday water constraints around flowering according to the classification proposed by Greenspan (2005), i.e. $\Psi_{\mathrm{L}}$ was more than -1 MPa (Table 6). No to low water constraints occurred around véraison. These relatively high values were comparable to the $\Psi_{\mathrm{L}}$ reported for Barlinka table grapes irrigated at 10\% PAW depletion in the Hex River Valley (Myburgh, 1996). In the 2002/03 season, low water constraints occurred during berry ripening (Table 4), whereas the grapevines experienced low to moderate constraints in 2003/04 (Table 6). A similar tendency towards more water constraints during berry ripening than flowering and véraison was reported for Barlinka irrigated at 10\% PAW depletion (Myburgh, 1996). Low to moderate water constraints during berry ripening also occurred in Sultanina irrigated at 30\% PAW depletion (Myburgh, 2003), and Sunred Seedless irrigated at 20\% PAW depletion (Myburgh \& Howell, 2006). Crop load did not have any effect on midday $\Psi_{L}$ (Tables 4 \& 6). Although the DF strategy tended to reduce predawn water constraints compared to less frequent irrigation, this trend did not reflect in the midday $\Psi_{L}$. The effect of the higher soil water availability on grapevine water status was probably negated by stomatal control during the warmest part of the day. Daytime oscillations in the transpiration of Sunred Seedless (Myburgh \& Howell, 2006) and $\Psi_{L}$ in Sultanina (Myburgh, 2007) indicated that stomatal control can contribute to negating the effects of differences in soil water availability on grapevine water status. Less sensitive responses of midday $\Psi_{\mathrm{L}}$ to variations in soil water content compared to $\Psi_{\mathrm{PD}}$ and stem water potential $\left(\Psi_{\mathrm{S}}\right)$ have also been observed in other grapevine cultivars (Bruwer, 2010; Myburgh, 2011a). Monitoring diurnal $\Psi_{L}$ patterns revealed that the DF grapevines also experienced fewer water constraints in the late afternoon and throughout the night than the LF and WF grapevines (data not shown). The higher $\Psi_{L}$ in the DF grapevines indicated that daily pulse irrigation allowed more rapid recovery from midday water constraints during the afternoon and night, compared to the less frequently irrigated grapevines. The lower water constraints in the afternoon could be beneficial to processes such as photosynthesis, whereas lower constraints during the night could enhance cell enlargement and growth (Myburgh, 1996).

\section{Total diurnal water status}

Except for the low $\Psi_{\text {Tot }}$ measured around veraison in the weekly fertigated grapevines bearing the normal crop load $\left(\mathrm{WF}_{\mathrm{N}}\right)$, the various fertigation strategies had no effect on $\Psi_{\text {Tot }}$ around flowering and véraison (Table 7). According to the water constraint classification based on $\Psi_{\text {Tot }}$ proposed by Myburgh (2011a), the grapevines experienced no water constraints, irrespective of the fertigation strategy, until véraison. The cumulative diurnal $\Psi_{\mathrm{L}}$ during berry ripening was comparable to $\Psi_{\text {Tot }}$ reported for micro-sprinkler irrigated Sunred Seedless grapevines in a sandy soil in the Hex River Valley at the end of January (Myburgh \& Howell, 2006). However, $\Psi_{\text {Tot }}$ was considerably lower than the $c a .32 \mathrm{MPa}^{2}$ measured in non-irrigated Merlot grapevines near Wellington during ripening in February (Myburgh, 2011a). In the 2002/03 season, the seven daily irrigation pulses reduced $\Psi_{\text {Tot }}$ in the grapevines compared to the LF and WF strategies (Table 4). The same trend occurred in the 2003/04 season, when the DF grapevines received only five pulses per day and the LF and WF ones received weekly irrigations. Since 
TABLE 6

Effect of low frequency (LF), weekly (WF) and daily pulse (DF) fertigation and crop load on midday leaf water potential ( $\left.\Psi_{\mathrm{L}}\right)$ during various growth stages in Dan-ben-Hannah grapevines determined during the 2003/04 season near Paarl in the Berg River Valley region.

\begin{tabular}{lllccc}
\hline \multirow{2}{*}{ Treatment } & $\begin{array}{l}\text { Fertigation } \\
\text { strategy }\end{array}$ & $\begin{array}{l}\text { Irrigation } \\
\text { frequency }\end{array}$ & Flowering(1) & Véraison & Berry ripening \\
\cline { 4 - 6 } & 3 times/season & weekly & $-0.86 \mathrm{a}^{(3)}$ & $-0.99 \mathrm{a}$ & $-1.19 \mathrm{a}$ \\
$\mathrm{LF}_{\mathrm{N}}^{(2)}$ & 3 times/season & weekly & - & $-1.06 \mathrm{a}$ & $-1.28 \mathrm{a}$ \\
$\mathrm{LF}_{\mathrm{H}}$ & weekly & weekly & $-0.85 \mathrm{a}$ & $-0.93 \mathrm{a}$ & $-1.21 \mathrm{a}$ \\
$\mathrm{WF}_{\mathrm{N}}$ & weekly & weekly & - & $-1.04 \mathrm{a}$ & $-1.26 \mathrm{a}$ \\
$\mathrm{WF}_{\mathrm{H}}$ & daily pulses & daily pulses & $-0.83 \mathrm{a}$ & $-1.04 \mathrm{a}$ & $-1.21 \mathrm{a}$ \\
$\mathrm{DF}_{\mathrm{N}}$ & daily pulses & daily pulses & - & $-1.04 \mathrm{a}$ & $-1.18 \mathrm{a}$ \\
$\mathrm{DF}_{\mathrm{H}}$ & & &
\end{tabular}

(1) No bunches were removed at that stage.

(2) $\mathrm{N}=$ normal crop load, i.e. 26 bunches per grapevine, and $\mathrm{H}=$ high crop load, i.e. 36 bunches per grapevine.

(3) Values designated by the same letter within each column do not differ significantly $(\mathrm{p} \leq 0.05)$.

TABLE 7

Effect of low frequency (LF), weekly (WF) and daily pulse (DF) fertigation and crop load on total diurnal leaf water potential $\left(\Psi_{\mathrm{Tot}}\right)$ during various growth stages in Dan-ben-Hannah grapevines determined during the 2003/04 season near Paarl in the Berg River Valley region.

\begin{tabular}{lllccc}
\hline \multirow{2}{*}{ Treatment } & $\begin{array}{l}\text { Fertigation } \\
\text { strategy }\end{array}$ & $\begin{array}{l}\text { Irrigation } \\
\text { frequency }\end{array}$ & Flowering(1) & Véraison & Berry ripening \\
\cline { 4 - 5 } & 3 times/season & weekly & $8.4 \mathrm{a}^{(3)}$ & $9.5 \mathrm{ab}$ & $15.4 \mathrm{ab}$ \\
$\mathrm{LF}_{\mathrm{N}}^{(2)}$ & 3 times/season & weekly & - & $9.4 \mathrm{ab}$ & $15.8 \mathrm{a}$ \\
$\mathrm{LF}_{\mathrm{H}}$ & weekly & weekly & $8.6 \mathrm{a}$ & $8.6 \mathrm{~b}$ & $14.9 \mathrm{~b}$ \\
$\mathrm{WF}_{\mathrm{N}}$ & weekly & weekly & - & $9.6 \mathrm{a}$ & $15.5 \mathrm{a}$ \\
$\mathrm{WF}_{\mathrm{H}}$ & daily pulses & daily pulses & $8.7 \mathrm{a}$ & $9.7 \mathrm{a}$ & $12.8 \mathrm{c}$ \\
$\mathrm{DF}_{\mathrm{N}}$ & daily pulses & daily pulses & - & $9.9 \mathrm{a}$ & $13.4 \mathrm{c}$ \\
$\mathrm{DF}_{\mathrm{H}}$ & & &
\end{tabular}

(1) No bunches were removed at that stage.

(2) $\mathrm{N}=$ normal crop load, i.e. 26 bunches per grapevine, and $\mathrm{H}=$ high crop load, i.e. 36 bunches per grapevine.

(3) Values designated by the same letter within each column do not differ significantly $(\mathrm{p} \leq 0.05)$.

the lower water constraints in the DF grapevines reflected inconsistently in predawn $\Psi_{L}$, and not at all in midday $\Psi_{L}$, these results suggest that small, but constant, $\Psi_{\mathrm{L}}$ differences over the course of the day could have a significant effect on the cumulative diurnal grapevine water status. If these diurnal differences occur continuously during a specific phenological phase, e.g. berry development or berry ripening, their cumulative effects could have significant effects on grapevine responses in terms of vegetative growth, yield or fruit quality. The foregoing shows that $\Psi_{\text {Tot }}$ is a more realistic indicator of water constraint response to $\Psi_{m}$ than midday $\Psi_{L}$ or even $\Psi_{\mathrm{PD}}$, particularly during berry ripening. Under the given conditions, $\Psi_{\text {Tot }}$ in the LF and WF normal crop load grapevines $\left(\mathrm{LF}_{\mathrm{N}}\right.$ and $\left.\mathrm{WF}_{\mathrm{N}}\right)$ tended to be lower than in their counterparts bearing the higher crop load in the 2002/03 season (Table 4). In the second season, $\Psi_{\text {Tot }}$ in the $\mathrm{WF}_{\mathrm{N}}$ was lower compared to the $\mathrm{WF}_{\mathrm{N}}$ grapevines around véraison and during berry ripening (Table 7). At this stage, there is no explanation for this trend. In the case of the daily pulse irrigated grapevines, crop load did not have any effect on $\Psi_{\text {Tot. }}$. This indicates that the daily pulses were able to supply adequate water so that the higher crop load did not induce more water constraints in the grapevines.

\section{CONCLUSIONS}

Weekly irrigations were sufficient to prevent any grapevine water constraints during the warmest part of the growing season. Where root systems are limited, more frequent irrigations might be necessary to avoid water constraints. Under the given conditions, it was possible to maintain $\Psi_{\mathrm{m}}$ above $-0.01 \mathrm{MPa}$ in the small wetted soil volumes where several irrigation pulses were applied during the daytime. However, daily pulses required substantially more water than three irrigations per week, or once a week, which could lead to less efficient use of irrigation water. To reduce the risk of insufficient water supply to the grapevines during heat waves, intensive monitoring of the soil water status is essential if daily irrigation pulses are applied. In order to prevent a gradual increase in the wetted soil volume, soil water status should also be monitored outside and below the wetted bulbs. Daily irrigation pulses caused the original root structure to adapt by forming extremely dense root systems in the small wetted bulbs. The grapevines that received daily pulse irrigation experienced less water constraints in the 
early parts of the morning, late afternoon and throughout the night than less frequently irrigated grapevines. Daily irrigation pulses did not prevent the daytime decrease in $\Psi_{\mathrm{L}}$, indicating that atmospheric conditions will cause $\Psi_{\mathrm{L}}$ to decrease during the daytime, irrespective of the level of soil water availability. The results confirmed that $\Psi_{\mathrm{L}}$ seemed to be a less sensitive indicator of grapevine water status in response to soil water status than $\Psi_{\mathrm{PD}}$. However, at high levels of soil water availability, an "ultra-low" class, viz. $\Psi_{\mathrm{PD}}>-0.1 \mathrm{MPa}$, should be included in the water constraint classification. Daily irrigation pulses consistently reduced $\Psi_{\text {Tot }}$ compared to less frequent irrigation. Hence, $\Psi_{\text {Tot }}$ might be a more realistic indicator of grapevine water status than $\Psi_{\mathrm{PD}}$ if soil water availability is high, as in the case of table grapes. The foregoing confirms that the high root densities in the wetted bulbs of the daily irrigated grapevines were able to meet the water demands of the full-bearing Dan-ben-Hannah grapevines. Furthermore, it was evident that grapevine functioning does not necessarily depend on the size of the root structure, but also on the environment in which the roots must function, particularly in terms of water absorption. A high crop load of 36 bunches per grapevine did not effect $\Psi_{\mathrm{PD}}$ or $\Psi_{L}$ compared to the 26 bunches per grapevine normally recommended, irrespective of the fertigation strategy or growth stage. Grapevines were not subjected to any form of detrimental water constraints throughout the season, irrespective of irrigation interval, fertilisation frequency or crop load. Based on the latter, daily pulse irrigation could only be recommended if the $c a$. $60 \%$ to $90 \%$ more irrigation water could be justified in terms of yield and/or quality increases compared to the other fertigation strategies. The effects of the fertigation strategies on the nutritional status, yield and fruit quality of Dan-ben-Hannah grapevines will be reported and discussed in subsequent articles.

\section{LITERATURE CITED}

Avenant, J.H., 1991. Trellising systems: gable or double slanting trellis. Farming in South Africa VORI 275/1991, ARC Infruitec-Nietvoorbij, Private Bag X5026, Stellenbosch 7599, South Africa.

Böhm, W., 1979. Methods of studying root systems. Springer Verlag, Berlin.

Bravdo, B., 2000. Effect of mineral nutrition and salinity on grape production and wine quality. Acta Hort. 512, 23-30.

Bravdo, B., 2008. Nutrient management in table and wine grapes by fertigation. Acta Hort. 785, 165-174.

Bruwer, R.J., 2010. The edaphic and climatic effects on production and wine quality of Cabernet Sauvignon in the Lower Olifants River region. Thesis, Stellenbosch University, Private Bag X1, Matieland 7602, South Africa.

Comas, L.H., Bauerle, T.L. \& Eissenstat, D.M., 2010. Biological and environmental factors controlling root dynamics and function: effects of root ageing and soil moisture. Aust. J. Grape Wine Res. 16, 131-137.

Conradie, W.J. \& Myburgh, P.A., 2000. Fertigation of Vitis vinifera L. cv. Bukettraube/110 Richter on a sandy soil. S. Afr. J. Enol. Vitic. 21, 40-47.

Dasgan, H.Y. \& Ekici, B., 2005. Comparison of open and recycling systems for ion accumulation of substrate, nutrient uptake and water and water use of tomato plants. Acta Hort. 697, 399-408.

Deloire, A., Carbonneau, A., Wang, Z. \& Ojeda, H., 2004. Vine and water: a short review. J. Int. Sci. Vigne Vin 38, 1-13.
El-Ansary, D.O., Nakayama, S., Hirano, K. \& Okamoto, G., 2005. Response of Muscat Alexandria table grapes to post-veraison regulated deficit irrigation in Japan. Vitis 35, 45-46.

Fascella, G. \& Zizzo, G.V., 2005. Effect of growing media on yield and quality of soilless cultivated rose. Acta Hort. 697, 133-138.

Fourie, A., 1989. The effect of four soil water regimes on the performance of Barlinka table grapes in the Hex River Valley. Thesis, Stellenbosch University, Private Bag X1, 7602 Matieland, South Africa.

Greenspan, M., 2005. Integrated irrigation of California winegrapes. Prac. Vineyard \& Winery March/April 2005, 21-79.

Hurndall, R., 2005. A guide to deciduous fruit of South Africa. Deciduous Fruit Producers' Trust, P.O. Box 163, 7622 Paarl.

Komosa, A., Pacholak, E., Stafecka, A. \& Treder, W., 1999a. Changes in nutrient distribution in apple orchard soil as the effect of fertigation and irrigation. I. Ammonium and nitrates. J. Fruit Ornam. Plant Res. VII, 27-40.

Komosa, A., Pacholak, E., Stafecka, A. \& Treder, W., 1999b. Changes in nutrient distribution in apple orchard soil as the effect of fertigation and irrigation. II. Phosphorus, potassium and magnesium. J. Fruit Ornam. Plant Res. VII, 71-80.

Larson, R.E., Hostetler, R.P. \& Edwards, B.H., 1994. Calculus with analytic geometry. D.C. Heath and Company, Massachusetts.

Le Roux, E.G., 1974. A climate classification for the South Western Cape viticultural areas (in Afrikaans). Thesis, Stellenbosch University, Private Bag X1, Matieland 7602, South Africa.

Ley, T.W., 1994. Irrigation system evaluation and improvement. In: Williams, K.M. \& Ley, T.W. (eds). Tree fruit irrigation: a comprehensive manual of deciduous tree fruit irrigation needs. Good Fruit Grower, Yakima, Washington. pp. $203-221$.

Maboko, M.M. \& Du Plooy, C.P., 2008. Effect of pruning on yield and quality of hydroponically grown cherry tomato (Lycopersicon esculentum). S. Afr. J. Plant Soil 25, 178-181.

Maboko, M.M., Du Plooy, C.P. \& Bertling, I., 2009. Comparative performance of tomato cultivars in soilless vs. in-soil production systems. Acta Hort. 843, 319-326.

Mollafilabi, A., Hassan Zadeh Rad, K., Aroiee, H., Sadrabadi Haghighi, R., Jahedi Pour, S. \& Taghi Ebadi, M., 2010. Effect of optimizing nitrogen and potassium application in Johnson nutrient solution on essential oil content of peppermint in hydroponics culture. Acta Hort. 853, 157-160.

Myburgh, P.A., 1996. Response of Vitis vinifera L. cv. Barlinka/Ramsey to soil water depletion levels with particular reference to trunk growth parameters. S. Afr. J. Enol. Vitic. 17, 3-14.

Myburgh, P.A., 2003. Responses of Vitis vinifera L. cv. Sultanina to level of soil water depletion under semi-arid conditions. S. Afr. J. Enol. Vitic. 24, 16-24.

Myburgh, P.A., 2007. An investigation into possible water savings with subsurface irrigation (Part II) - Plant water stress, growth, yield and quality. Wynboer Technical Yearbook 2007, 38-42.

Myburgh, P.A., 2010. Practical guidelines for the measurement of water potential in grapevine leaves. Wynboer Technical Yearbook 2010, 11-13.

Myburgh, P.A., 2011a. Response of Vitis vinifera L. cv. Merlot to low frequency drip irrigation and partial root zone drying in the Western Cape Coastal region - Part I. Soil and plant water status. S. Afr. J. Enol. Vitic. 32, 89-103.

Myburgh, P.A., 2011b. Response of Vitis vinifera L. cv. Merlot to low frequency drip irrigation and partial root zone drying in the Western Cape Coastal region - Part II. Soil and plant water status. S. Afr. J. Enol. Vitic. 32, 104-116. 
Myburgh, P.A. \& Howell, C.L., 2006. Water relations of Vitis vinifera L. cv. Sunred Seedless in response to soil water depletion before harvest. S. Afr. J. Enol. Vitic. 27, 196-201.

Myburgh, P.A. \& Howell, C.L., 2007. Evapotranspiration of Vitis vinifera L. cvs Sunred Seedless and Muscat Supreme in response to soil water depletion and irrigation cutoff during berry ripening. S. Afr. J. Plant Soil 24, 209-313.

Pérez-Harvey, J. 2008. Nutrition and irrigation related problems in table grapes. Acta Hort. 785, 175-182.

Reynolds, A.G., Lowrey, W.D. \& De Savigny, C., 2005. Influence of irrigation and fertigation on fruit composition, vine performance, and water relations of Concord and Niagara grapevines. Am. J. Enol. Vitic. 56, 110128 .

Saayman, D. \& Lambrechts, J.J.N., 1995. The effect of irrigation system and crop load on the vigour of Barlinka table grapes on a sandy soil, Hex River Valley. S. Afr. J. Enol. Vitic. 16, 26-34.

Scholander, P.F., Hammel, H.T., Bradstreet, E.D. \& Hemmingsen, E.A., 1965. Sap flow in vascular plants. Science 148, 339-346.
Sharma, J., Upadhyay, A.K., Shikhamany, S.D. \& Singh, R.K., 2008. Effect of fertilizer application through irrigation water on Thompson Seedless grape yield and fertilizer use efficiency. Acta Hort. 785, 399-408.

Soil Classification Work Group, 1991. Soil classification - A taxonomic system for South Africa. Memoirs on natural resources of South Africa no. 15. Dept. Agric. Developm., Private Bag X116, 0001 Pretoria, South Africa.

Treder, W., 2005. Variation in soil $\mathrm{pH}$, calcium and magnesium status influenced by drip irrigation and fertigation. J. Fruit Ornam. Plant Res. 13, $59-70$.

Van Rooyen, F.C., Weber, H.W. \& Levin, I., 1980. The response of grapes to a manipulation of the soil-plant-atmosphere continuum. I. Growth, yield and quality responses. Agrochemophysica 12, 59-68.

Van Zyl, J.L., 1984. Interrelationships among soil water regime, irrigation and water stress in the grapevine (Vitis vinifera $\mathrm{L}$ ). Dissertation, Stellenbosch University, Private Bag X1, Matieland 7602, South Africa.

Winkler, A.J., 1962. General viticulture. University of California Press, Los Angeles. 